Kinga Stępień*

\title{
KILKA UWAG O BADANIU EFEKTYWNOŚCI BANKÓW. PRZYPADEK POLSKI
}

\section{Wprowadzenie}

Efektywność banku jako kategoria pojęciowa jest różnorodnie i niejednoznacznie rozumiana. Przegląd sposobów pojmowania tego pojęcia w literaturze wskazuje, że można ją rozpatrywać w kontekście ekonomicznym lub teorii organizacji ${ }^{1}$. Z powodu różnorodności zaobserwowanej na płaszczyźnie definicyjnej analizy efektywności prowadzone są z zastosowaniem różnych narzędzi analitycznych. Pomijając na tym etapie dyskurs o spektrum narzędziowym ${ }^{2}$, można ogólnie wyróżnić dwa kierunki badań nad efektywnością - analizy efektywności technicznej (technical efficiency) oraz analizy efektów skali i zakresu produkcji (scale and scope efficiency) ${ }^{3}$. Zastosowanie znajdują tu klasyczne i nieklasyczne metody pomiaru ${ }^{4}$. W drugiej grupie można wyróżnić metodę Data Envelopment Analysis (DEA), Analytic Hierarchy Process (AHP) oraz sztuczne sieci neuronowe ${ }^{5}$.

* Politechnika Rzeszowska, Wydział Zarządzania.

1 Zob. M. Capiga, Efektywność jako kryterium oceny banku, „Bank” 2002, nr 3, s. 49; G. Rogowski, Metodologia analiz efektywności i efektu skali banków, „Bank i Kredyt” 1998, nr 11, s. 28; M. Pawłowska, Efektywność, konkurencyjność i koncentracja na polskim rynku usług bankowych w latach 1997-2002 - związki między pojęciami, „Bank i Kredyt” 2003, nr 6, s. 59; K. Stępień, Konsolidacja a efektywność banków w Polsce, CeDeWu, Warszawa 2004, s. 65; T. Siudek, Wpływ poziomu konkurencji na efektywność działania banków spótdzielczych w Polsce - teoria i praktyka, Szkoła Główna Gospodarstwa Wiejskiego w Warszawie, „Roczniki Naukowe" 2008, t. 10, z. 1, s. 376.

2 Można wyróżnić trzy grupy metod analizy banku w kontekście efektywności: metody z zakresu analizy finansowej, z zakresu zarządzania strategicznego oraz metody ilościowe z zakresu statystyki, ekonometrii i badań operacyjnych.

3 G. Rogowski, Metody analizy i oceny działalności banku na potrzeby zarzadzania strategicznego, Wyd. Wyższej Szkoły Bankowej w Poznaniu, Poznań 1998, s. 61.

4 Ibidem, s. 118

5 M. Gospodarowicz, Procedury analizy i oceny banków, „Materiały i Studia NBP” 2000, nr 103; K. Jajuga, Statystyczna analiza wielowymiarowa, PWN, Warszawa 1993; M. Pawłowska, Wpływ zmian w strukturze polskiego sektora bankowego na jego efektywność w latach 1997-2002 (podejście nieparametryczne), „Bank i Kredyt" 2003, nr 11-12. 
Pomimo niekwestionowanych zalet metody DEA, w trakcie badań nad efektywnością banków, napotkano pewne ograniczenia ${ }^{6}$. Jednym ze zdiagnozowanych dylematów na płaszczyźnie teoretycznej i empirycznej jest zdefiniowanie efektu produkcji w banku. Bariery na tym etapie wynikają ze specyficznego charakteru usług bankowych oraz szerokiego asortymentu i złożoności usług oferowanych przez banki. Wydaje się, że kwestia ta stanowi jedną z najbardziej kontrowersyjnych i złożonych we współczesnej nauce oraz praktyce bankowości. Celem artykułu jest zaprezentowanie kilku konkluzji wynikających z kompleksowego badania efektywności banków w Polsce z zastosowaniem metody DEA w latach 1996-2007. Artykuł oparto na wynikach badań K. Chudy, M. Sobolewskiego, K. Stępień z 2012 r. Niniejsze opracowanie otwiera cykl artykułów dotyczących dylematów pomiaru efektywności i produktywności banków. W części pierwszej opracowania omówiono wybrane problemy metodologiczne związane z zastosowaniem metody DEA w analizie efektywności banków, które napotyka się na etapie doboru zmiennych do zbioru nakładów i efektów działania banku. W drugiej części przedstawiono wyniki badania efektywności banków na podstawie dwu koncepcji - koncepcji pośrednika (intemediation approach) i producenta (production approach). Artykuł zamyka podsumowanie.

\section{Koncepcje nakładów i efektów}

W literaturze brak jest jednoznacznej i kompleksowej definicji banku w kontekście definiowania nakładów oraz efektów jego działalności. Jest to rezultatem złożonego charakteru funkcjonowania banku jako przedsiębiorstwa usługowego, a także zmieniających się warunków otoczenia banku ${ }^{7}$. Na etapie doboru zmiennych do szacowania efektywności banku można przyjąć, że bank jest pośrednikiem finansowym lub producentem usług finansowych. Oba podejścia mają swoje źródło w mikroekonomicznej teorii przedsiębiorstwa zaadaptowanej do analizy funkcjonowania przedsiębiorstwa bankowego.

W podejściu pośrednika podkreśla się działalność banku polegającą na przyjmowaniu wkładów klientów oraz dostarczaniu kredytów i innych środków inwestycyjnych ${ }^{8}$. Uwzględnia się tu funkcje transformacji terminu, kwot i ryzyka przyjmując,

6 Szerzej o zaletach i wadach DEA K. Stępień, op.cit., s. 144-145.

7 M. Pawłowska, Konkurencja w sektorze bankowym. Teoria i wyniki empiryczne, C.H. Beck, Warszawa 2014, s. 31 .

8 J.A. Bikker, J.W.B. Bos, Bank Performance. A theoretical and empirical framework for analysis of profitability, competition and efficiency, Routlege International Studies in Money and Banking, 2008. 
że nakłady banku stanowi kapitał finansowy, przez który rozumie się depozyty oraz fundusze pożyczone na rynku finansowym, a także kapitał rzeczowy. Efekty mierzy się wartością udzielonych kredytów oraz posiadanego przez bank portfela inwestycyjnego. Depozyty traktowane są w tym wypadku jako nakłady banku. W. Sealey i J.T. Lindley wskazywali, że depozyty powinny być traktowane jako nakłady dlatego, że do zwiększenia poziomu produkcji w banku przyczyniają się jedynie aktywa dochodowe, takie jak kredyty i papiery wartościowe?

W koncepcji producenta (production approach), proponowanej przez D. B. Humpreya, G.J. Benstona oraz F.W. Bella i N.B. Murphy’ego jako główny cel banku definiowana jest produkcja usług bankowych dla posiadaczy rachunków ${ }^{10}$. Rezultaty działalności banku są mierzone w sposób, w którym przyjmuje się, że bank jest przedsiębiorstwem wykorzystującym kapitał i siłę roboczą do wytworzenia różnego rodzaju depozytów i kredytów ${ }^{11}$. Nakładami są w tym wypadku wydatki nieodsetkowe (koszty osobowe, materiałowe, koszty amortyzacji budynków i gruntów), efektami zaś liczba przeprowadzonych transakcji lub prowadzonych rachunków (wkłady terminowe, oszczędnościowe, rachunki bieżące, kredyty hipoteczne, konsumenckie). $\mathrm{W}$ ujęciu producenta $\mathrm{z}$ analizy wyklucza się koszty odsetkowe, a uwzględnia koszty zasobów ludzkich i kapitału, czyli koszty operacyjne. Zastosowanie podejścia producenta w praktyce spotyka się z kwestią pomiaru wolumenu produktów banku. Trudno rozstrzygnąć tu jednoznacznie, czy efekty działania banku należy ujmować w liczbie rachunków, liczbie operacji prowadzonych na rachunkach czy też w kwocie obrotów. W ogólnie przyjętym podejściu zastosowanie mają kwoty obrotów, o których dane są bardziej dostępne ${ }^{12}$. J. Kolari i A. Zardkoohi wskazywali, że do pomiaru efektów banku można używać wolumenu kwot zgromadzonych na rachunkach bankowych zamiast liczby tych rachunków z tego powodu, że banki zwiększają swój udział w rynku poprzez wzrost kwot na rachunkach, nie zaś zwiększenie ich liczby ${ }^{13}$. Ponadto ze względu na wieloasortymentowy charakter produkcji banku ujmowanie efektów w wolumenie kwot stanowi jedyne rozsądne rozwiązanie ${ }^{14}$.

9 C.W. Sealey, J.T. Lindley, Inputs, Ouputs and Theory of Production and Cost for Financial Institutions, "Jorurnal of Finance" 1997, nr 32.

${ }^{10}$ D.B. Humprey, Cost and Scale Economies in Bank Intermediation, w: Handbook for Banking Strategy, R. Aspinwall, R. Eisenbeis, Wiley\&Sons, New York 1985; F.W. Bell, N.B. Murphy, Economies of scale and division of labor in commercial banking, "National Banking Review" 1968, No. 5, s. 131-139; G.J. Benston Branch Banking and Economies of Scale, "Journal of Banking and Finance" 1965, No. 20, s. 312-331.

${ }^{11}$ S. Heffernan, Nowoczesna bankowość, PWN, Warszawa 2007, s. 587-592.

12 X. Freixas, J.Ch. Rochet, Mikroekonomia bankowa, CeDeWu, Warszawa 2007, s. 119.

${ }^{13}$ J. Kolari, A. Zardkoohi, Bank Cost, Structure and Performance, Lexington Books, Lexington 1987.

14 B. Casu, P. Molyneux, Efficiency in European banking, w: European banking. Efficiency, Technology and Growth, J. Goddard, P. Molymeux, J.O.S. Wilson, Wiley, 2001, s. 99-140. 
A.N. Berger i D.B. Humprey wskazują, że w żadnej z omówionych dwu koncepcji funkcjonowania banku nie odzwierciedla się w pełni dualnej roli banku, polegającej na transformacji funduszy od deponentów do kredytobiorców oraz zapewnianiu klientom różnego rodzaju transakcji rozliczeniowych ${ }^{15}$. Uważa się, że efektywność całego banku pełniej jest szacowana na podstawie koncepcji pośrednika, ponieważ w analizie są uwzględnione wszystkie koszty wraz z kosztami odsetkowymi, które mogą stanowić połowę lub więcej całkowitych kosztów banku oraz transformacja pieniądza, terminu i ryzyka.

Koncepcja producenta jest bardziej przydatna podczas badania wydajności banku przy wypełnianiu jego zadań związanych z prowadzeniem kont. W wypadku dużych banków stosowanie koncepcji producenta może przyczyniać się do przeszacowania rozmiarów efektów skali ${ }^{16}$. Podejście produkcyjne jest bardziej przydatne do oceny efektywności pojedynczego oddziału banku z tego powodu, że jedynymi produktami oddziału banku są usługi świadczone na rzecz deponentów oraz kredytobiorców, zaś nakładami praca i kapitał fizyczny ${ }^{17}$. S. Heffernan podkreśla, że koncepcja producenta i pośrednika wyklucza uwzględnienie w analizie efektywności stopnia ryzyka poszczególnych kredytów czy reputacji banku w kontekście prawdopodobieństwa jego upadłości oraz czasowej struktury depozytów i kredytów ${ }^{18}$. Badania efektywności wykorzystujące to podejście zostały zaprezentowane m.in. w pracach G.J. Benstona i R.A. Gilberta oraz G.D. Ferriera i C.A.K. Lovella ${ }^{19}$.

Z koncepcji pośrednika wywodzą się inne sposoby modelowania technologii bankowej. D.C. Wheelock i P.W. Wilson dokonują tu rozróżnienia na podejście zasobów finansowych (asset approach), wartości dodanej (value added approach) oraz kosztu użytkownika (user cost) $)^{20}$. W pierwszym wypadku przyjmuje się założenie, że bank produkuje różne rodzaje kredytów oraz dokonuje inwestycji, angażując w ten proces przyjęte depozyty, fundusze innego rodzaju, siłę roboczą oraz majątek trwały. Pomija się jednocześnie fakt, że bank angażuje także znaczne zasoby do przeprowadzania różnego typu transakcji oraz obsługi rachunków oszczędnościowych. Koncepcja

${ }^{15}$ A.N. Berger, D.B. Humprey, Megemergers in banking and the use of cost efficiency as an antitrust defense, "Antitrust Bulletin" 1992, No. 37, s. 541-600.

${ }^{16}$ G. Sheldon, Nichtparametrische Messung des technischen Fortschritts im Schweizer Bankgewerbe, „Schweizerische Zeitung fur Volkswirtschaft und Statistik” 1994, No. 130, s. 16.

17 X. Freixas, J.Ch. Rochet, op.cit., s. 119.

18 S. Heffernan, Nowoczesna bankowość, PWN, Warszawa 2007, s. 587-590.

19 G.J. Benston, op.cit., s. 312-331; R.A. Gilbert, Bank Market Structure and Competition: A Survey, "Journal of Money, Credit and Banking" 1984, Vol. 16, No. 4, s. 617-645; G.D. Ferrier, C.A.K. Lovell C.A.K., Measuring Cost Efficiency in Banking: Econometric and Linear Programming Evidence, "Journal of Econometrics" 1990, Vol. 46, No. 1-2, s. 229-245.

20 D.C. Wheelock, P.W. Wilson, Evaluating the Efficiency of Commercial Banks: Does Our View of What Banks Do Matter?, "Review of Federal Reserve Bank of St. Louis" 1995, Vol. 77, No. 7-8, s. 41. 
wartości dodanej zakłada, że efektem działalności banku jest każda aktywność, w której zużywane są jego zasoby. Wynika stąd, że zarówno wybrane kategorie aktywów jak i pasywów banku mogą być uznawane za efekty jego działalności, jeśli tworzą wartość dodaną. W podejściu kosztu użytkownika koszt składników aktywów jest kalkulowany jako różnica między kosztem alternatywnym kapitału banku i zwrotem z niego. Koszt składników pasywów jest wyznaczany jako różnica pomiędzy kosztem ich uzyskania a kosztem alternatywnym kapitału. Wybrane składniki aktywów i pasywów mogą być klasyfikowane zarówno jako nakłady, jak i efekty w działalności banku, w zależności od związanego z nimi kosztu użytkownika.

Istnieje zgoda co do tego, że kredyty i inne aktywa banku umieszcza się po stronie efektów jego działalności. Brak jest natomiast jednoznacznego ustalenia miejsca depozytów, które traktowane są jako nakłady lub jako efekty działalności bankowej. Oba te rozwiązania znajdują swoje uzasadnienie teoretyczne. Depozyty mogą być traktowane jako nakłady ze względu na to, że stanowią podstawę aktywności kredytowej banku. Mogą także być postrzegane jako efekty jego działalności, ponieważ zapewniają płynność oraz usługi płatnicze dla klientów ${ }^{21}$. Wyniki badań banków w Polsce wskazują, że poziom miar efektywności jest uzależniony od tego, czy depozyty zalicza się do nakładów, czy do efektów działalności bankowej ${ }^{22}$. Istnieją także dowody na to, że na otrzymane wyniki badań może wpływać sposób ujęcia i wyrażenia efektów ${ }^{23}$.

Należy zaznaczyć, że trudności w badaniach empirycznych uwzględniających omówione koncepcje wynikają także z innych przyczyn, m.in. z konieczności zgromadzenia danych empirycznych dotyczących nakładów i efektów. Zdecydowanie więcej analiz przeprowadza się z wykorzystaniem podejścia pośrednika, ponieważ w tym wypadku napotyka się mniejsze ograniczenia praktyczne w uzyskaniu danych.

${ }^{21}$ A.N. Berger, D.B. Humprey, Efficiency of Financial Institutions: International Survey and Directions for Future Research, "European Journal for Operational Research" 1997, No. 98, s. 175-212.

${ }^{22}$ K. Chudy, M. Sobolewski, K. Stępień, Wpływ umiejscowienia depozytów w nakładach lub efektach na produktywność banków giełdowych w Polsce, w: Wspótczesne Finanse. Stan i perspektywy rozwoju bankowości, red. L. Dziawgo, Wydawnictwo Naukowe Uniwersytetu Mikołaja Kopernika, Toruń 2008, s. 335-346; K. Chudy, M. Sobolewski, K. Stępień, Koncepcje funkcjonowania banku a zmiany produktywności banków giełdowych w Polsce, „Zeszyty Naukowe Uniwersytetu Szczecińskiego” 2009, Seria: Ekonomiczne problemy ustug, nr 548, s. 117-124; K. Chudy, M. Sobolewski, K. Stępień, Wplyw klasyfikacji nakładów i efektów w działalności banku na zmiany produktywności banków giełdowych w Polsce, Wydawnictwo Naukowe Politechniki Rzeszowskiej, Rzeszów 2009, „Zarządzanie i Marketing” 2009, nr 16, s. 65-73.

${ }_{23}$ B. Casu, P. Molyneux, Efficiency in European banking w: European banking. Efficiency, Technology and Growth, J. Goddard, P. Molyneux, J.O.S. Wilson, John Willey \& Sons, Ltd., 2001. 


\section{Wyniki badania efektywności banków}

\subsection{Model pośrednika}

Wskaźniki efektywności technicznej dla badanych banków otrzymane dla modelu pośrednika przedstawiono $\mathrm{w}$ tabeli $1^{24}$. W analizowanej grupie banków można wskazać te, które w całym okresie przyjętym do badania wykazywały wskaźnik $E_{\mathrm{VRS}}$ równy 1 . Są to Pekao, BRE, Bank Handlowy, Rabobank, AIG Bank, WestLB, ABN Amro. Banki te są jednostkami dominującymi dla pozostałych analizowanych banków.

Tabela 1. Wskaźniki efektywności technicznej przy założeniu zmiennych efektów skali $-E_{\text {VRS }}$

\begin{tabular}{|c|c|c|c|c|c|c|c|c|c|c|c|c|}
\hline \multirow{2}{*}{ Bank $^{\mathrm{a}}$} & \multicolumn{12}{|c|}{$E_{\mathrm{VRS}}$} \\
\hline & 1996 & 1997 & 1998 & 1999 & 2000 & 2001 & 2002 & 2003 & 2004 & 2005 & 2006 & 2007 \\
\hline Pekao & 1 & 1 & 1 & 1 & 1 & 1 & 1 & 1 & 1 & 1 & 1 & 1 \\
\hline PKO BP & 1 & 1 & 1 & 1 & 0,87 & 1 & 1 & 1 & 1 & 1 & 1 & 1 \\
\hline BRE Bank & 1 & 1 & 1 & 1 & 1 & 1 & 1 & 1 & 1 & 1 & 1 & 1 \\
\hline ING Bank Śląski & 1 & 1 & 1 & 0,96 & 1 & 1 & 1 & 0,87 & 1 & 1 & 1 & 1 \\
\hline BZ WBK & 1,00 & 1 & 0,99 & 0,93 & 0,96 & 0,86 & 0,85 & 0,90 & 0,94 & 1 & 0,92 & 0,92 \\
\hline Bank Handlowy & 1 & 1 & 1 & 1 & 1 & 1 & 1 & 1 & 1 & 1 & 1 & 1 \\
\hline Bank Millennium & 1 & 0,84 & 1 & 1 & 1 & 0,90 & 0,84 & 1 & 1 & 0,80 & 0,96 & 1 \\
\hline Kredyt Bank & 1 & 0,80 & 1 & 1 & 1 & 1 & 0,93 & 0,92 & 0,89 & 0,91 & 0,88 & 0,92 \\
\hline Bank BGŻ & 1 & 1 & 1 & 1 & 1 & 1 & 0,91 & 0,86 & 0,80 & 0,87 & 0,84 & 0,91 \\
\hline Raiffeisen Bank & 1 & 1 & 0,91 & 1 & 0,93 & 0,83 & 0,74 & 1,00 & 0,96 & 1 & 1 & 1 \\
\hline GETIN Bank & 1 & 0,89 & 1 & 0,86 & 0,79 & 1 & 0,72 & 0,83 & 0,69 & 0,83 & 0,90 & 1 \\
\hline GE Money Bank & 1 & 1 & 0,74 & 0,95 & 1 & 1 & 1 & 1 & 1 & 1 & 1 & 1 \\
\hline Fortis Bank & 1 & 1 & 0,93 & 0,81 & 0,84 & 0,79 & 0,77 & 0,86 & 0,90 & 0,90 & 0,74 & 0,95 \\
\hline Bank BPH & 1 & 0,94 & 1 & 0,96 & 1 & 1 & 1 & 1 & 1 & 1 & 1 & 1 \\
\hline Nordea Bank & 1 & 1 & 0,82 & 0,82 & 1 & 0,76 & 0,68 & 0,83 & 0,84 & 0,79 & 0,83 & 0,95 \\
\hline
\end{tabular}

${ }^{24} \mathrm{Na}$ podstawie koncepcji pośrednika zdefiniowano zbiór nakładów i efektów. Nakłady: majątek trwały, zatrudnienie oraz zobowiązania ogółem, efekty: należności ogółem, papiery wartościowe i wynik z tytułu prowizji. Zatrudnienie wyrażono w liczbie etatów, zaś pozostałe wielkości nakładów i efektów w złotych, urealnione do poziomu cen z 2008 r. W celu obliczenia wskaźników efektywności technicznej badanych banków przyjęto model ukierunkowany na nakłady. Miary efektywności technicznej $E_{\mathrm{VRS}}$ (przy założeniu zmiennych efektów skali) otrzymano poprzez estymację odpowiednich modeli DEA. Poziom wskaźników efektywności technicznej zawiera się w przedziale od 0 do 1 . Wartość wskaźnika na poziomie równym 1 oznacza, że bank jest efektywny, jeśli natomiast poziom wskaźnika jest mniejszy niż 1, istnieje możliwość poprawy relacji nakładów do generowanych efektów. Podstawę analiz stanowiły dane bilansowe, dane $\mathrm{z}$ rachunku wyników oraz dane dotyczące zatrudnienia dla 27 banków funkcjonujących w Polsce w latach 1996-2007. 


\begin{tabular}{|l|l|l|l|l|l|l|l|l|l|l|l|l|}
\hline \multirow{2}{*}{ Bank $^{\mathrm{a}}$} & \multicolumn{10}{|c|}{$E_{\mathrm{VRS}}$} \\
\cline { 2 - 15 } & 1996 & 1997 & 1998 & 1999 & 2000 & 2001 & 2002 & 2003 & 2004 & 2005 & 2006 & 2007 \\
\hline BOŚ & 1 & 1 & 1 & 1 & 1 & 0,96 & 0,84 & 0,86 & 0,81 & 0,84 & 0,79 & 0,83 \\
\hline Lukas Bank & 0,94 & 0,81 & 1 & 1 & 1 & 1 & 1 & 1 & 0,89 & 0,94 & 0,92 & 0,93 \\
\hline Rabobank Polska & 1 & 1 & 1 & 1 & 1 & 1 & 1 & 1 & 1 & 1 & 1 & 1 \\
\hline Deutsche Bank & 1 & 0,86 & 1 & 1 & 1 & 1 & 1 & 1 & 1 & 1 & 1 & 1 \\
\hline Bank DnB Nord & 1 & 0,98 & 0,62 & 0,88 & 0,74 & 0,79 & 0,45 & 0,40 & 0,57 & 0,70 & 0,71 & 0,86 \\
\hline AIG Bank & 1 & 1 & 1 & 1 & 1 & 1 & 1 & 1 & 1 & 1 & 1 & 1 \\
\hline Bank Pocztowy & 0,96 & 1 & 0,85 & 1 & 1 & 0,84 & 0,98 & 1 & 1 & 1 & 1 & 1 \\
\hline West LB Bank & 1 & 1 & 1 & 1 & 1 & 1 & 1 & 1 & 1 & 1 & 1 & 1 \\
\hline Invest-Bank & 0,78 & 0,68 & 0,71 & 0,71 & 0,67 & 0,71 & 0,70 & 0,78 & 0,87 & 0,88 & 1 & 0,93 \\
\hline DZ Bank & 1 & 1 & 1 & 1 & 1 & 1 & 1 & 1 & 1 & 1 & 1 & 1 \\
\hline Dominet Bank & 0,86 & 0,84 & 0,87 & 0,80 & 1 & 1 & 1 & 0,92 & 1 & 1 & 1 & 1 \\
\hline ABN Amro Bank & 1 & 1 & 1 & 1 & 1 & 1 & 1 & 1 & 1 & 1 & 1 & 1 \\
\hline Średnia & $\mathbf{0 , 9 8}$ & $\mathbf{0 , 9 5}$ & $\mathbf{0 , 9 4}$ & $\mathbf{0 , 9 5}$ & $\mathbf{0 , 9 6}$ & $\mathbf{0 , 9 4}$ & $\mathbf{0 , 9 0}$ & $\mathbf{0 , 9 3}$ & $\mathbf{0 , 9 3}$ & $\mathbf{0 , 9 4}$ & $\mathbf{0 , 9 4}$ & $\mathbf{0 , 9 7}$ \\
\hline
\end{tabular}

a Ze względu na przekształcenia własnościowe i procesy fuzji i przejęć, które miały miejsce w sektorze bankowym w Polsce po $2007 \mathrm{r}$. niektóre banki zmieniły swoje nazwy lub połączyły się z innymi bankami w rezultacie przejęcia: 1. W wyniku przejęcia Kredyt Banku przez BZ WBK od 4.01.2013 r. bank funkcjonuje pod nazwa BZ WBK. 2. W wyniku połączenia Rabobanku i BGŻ od 18 czerwca 2014 r. bank funkcjonuje pod nazwą BGŻ. W I połowie 2015 r. planowana jest fuzja BGŻ i BNP Paribas. 3. Od 32.12.2012 r. w wyniku połączenia Raiffeisen i Polbank funkcjonuje pod nazwą Raiffeisen Polbank. 4. Na skutek przejęcia GE Money Banku przez BPH od 31.12.2009 r. bank funkcjonuje pod nazwą BPH. 5. 31 lipca 2009r. zakończyło się połączenie Fortis Banku i Dominet Banku. Od 31.04.2011 r. bank działa pod nazwą BNP Paribas. 6. 31 października 2014 r. Nordea Bank został przejęty przez PKO BP. 7. Od 23 września 2011 r. Lukas Bank, który został przejęty przez Credit Agricole działa pod nazwą Credit Agricole. 8. 1 marca 2011 r. nastąpiło połączenia AIG Banku z Santander Consumer Bankiem. 9. West LB Bank w 2010 r. zmienił nazwę na Polski Bank Przedsiębiorczości SA, w 2013 r. nastąpiła fuzja PBP SA z FM bankiem SA, w wyniku której powstał FM Bank PBP SA. 10. W 2008 r. ABN Amro Bank został przejęty przez konsorcjum banków Fortis, Banco Santander i Royal Bank of Scotland. Obecnie działa jako RBS Bank Polska SA.

Źródło: Opracowanie własne na podstawie K. Chudy, M. Sobolewski, K. Stępień, Analiza efektywności banków w Polsce w latach 1996-2007, Oficyna Wydawnicza Politechniki Rzeszowskiej, Rzeszów 2012.

W poszczególnych latach różna była liczba banków, które charakteryzowały się nieefektywnością techniczną. W 1996 r. tylko cztery banki wykazywały nieefektywność techniczną, w pozostałych latach liczba ta wahała się od 12 do siedmiu. Najwyższy średni poziom efektywności dla analizowanych 27 banków uzyskano w $1996 \mathrm{r}$. i 2007 r. (odpowiednio 0,98 i 0,97), najniższy natomiast w 2002 r. $(0,90)$.

Dwa banki (PKO BP i Deutsche Bank) w okresie 1996-2007 tylko w jednym roku wykazywały nieefektywność techniczną. W wypadku PKO BP miało to miejsce w 2000 r., zaś w przypadku Deutsche Banku w 1997 r. Analiza kształtowania się poziomu wskaźnika efektywności technicznej wśród dużych banków uniwersalnych wskazuje, że nie ma jednolitej tendencji w tym zakresie. Przykładowo BZ WBK tylko $\mathrm{w}$ dwóch analizowanych latach funkcjonował efektywnie w porównaniu $\mathrm{z}$ innymi 
bankami. W Banku Millennium na przemian występowały okresy, kiedy bank uzyskiwał wskaźniki efektywności technicznej równe 1, z okresami gdy wykazywał nieefektywność techniczną różnego rzędu. Kredyt Bank w początkowych latach analizy charakteryzował się głównie efektywnością, podczas gdy w latach 2002-2007 nieprzerwanie jest bankiem nieefektywnym technicznie.

\subsection{Model producenta}

Wskaźniki efektywności technicznej dla badanych banków otrzymane przy zastosowaniu modelu producenta przedstawiono $w$ tabeli $2^{25}$. Na podstawie ich poziomu zauważa się większe zróżnicowanie miar efektywności oraz większą liczbę banków, które uznaje się za jednostki dominujące, wyznaczające kształt krzywej granicznych możliwości produkcyjnych.

Tabela 2. Wskaźniki efektywności technicznej analizowanych banków przy założeniu zmiennych efektów skali w latach 1996-2007

\begin{tabular}{|c|c|c|c|c|c|c|c|c|c|c|c|c|}
\hline \multirow{2}{*}{ Bank } & \multicolumn{12}{|c|}{$E_{\mathrm{VRS}}$} \\
\hline & 1996 & 1997 & 1998 & 1999 & 2000 & 2001 & 2002 & 2003 & 2004 & 2005 & 2006 & 2007 \\
\hline Pekao & 1 & 0,78 & 1 & 1 & 1 & 1 & 1 & 1 & 1 & 1 & 0,97 & 1 \\
\hline PKO BP & 1 & 1 & 1 & 1 & 1 & 1 & 1 & 1 & 1 & 1 & 1 & 0,73 \\
\hline BRE Bank & 0,90 & 0,78 & 1 & 1 & 1 & 1 & 1 & 1 & 1 & 1 & 1 & 1 \\
\hline ING Bank Śląski & 0,64 & 0,53 & 0,68 & 0,69 & 0,84 & 1 & 0,94 & 0,87 & 0,91 & 1 & 1 & 1 \\
\hline BZ WBK & 0,43 & 0,74 & 0,75 & 0,83 & 0,72 & 0,62 & 0,68 & 0,73 & 0,70 & 0,82 & 0,51 & 0,53 \\
\hline Bank Handlowy & 1 & 1 & 1 & 1 & 1 & 1 & 1 & 1 & 0,61 & 0,64 & 0,68 & 0,59 \\
\hline Bank Millennium & 1 & 0,80 & 1 & 1 & 0,82 & 0,68 & 0,65 & 0,66 & 0,68 & 0,53 & 0,67 & 0,94 \\
\hline Kredyt Bank & 0,31 & 0,82 & 1 & 1 & 1 & 0,98 & 0,87 & 0,72 & 0,68 & 0,66 & 0,51 & 0,66 \\
\hline Bank BGŻ & 1 & 1 & 1 & 0,77 & 0,71 & 0,65 & 0,73 & 0,58 & 0,44 & 0,43 & 0,44 & 0,49 \\
\hline Raiffeisen Bank & 1 & 1 & 0,84 & 1 & 0,81 & 0,73 & 0,73 & 1 & 1 & 1 & 1 & 1 \\
\hline Fortis Bank & 0,31 & 0,18 & 0,15 & 0,26 & 0,54 & 0,47 & 0,24 & 0,34 & 0,47 & 0,18 & 0,86 & 0,87 \\
\hline Bank BPH & 0,57 & 0,62 & 0,76 & 0,76 & 0,94 & 1 & 1 & 1 & 1 & 1 & 1 & 0,14 \\
\hline Nordea Bank & 0,20 & 0,16 & 0,18 & 0,14 & 0,08 & 0,07 & 0,06 & 0,06 & 0,32 & 0,17 & 0,44 & 0,63 \\
\hline BOŚ & 0,71 & 0,94 & 0,72 & 0,55 & 0,67 & 0,67 & 0,83 & 0,52 & 0,46 & 0,31 & 0,39 & 0,19 \\
\hline Bank DnB Nord & 0,34 & 0,31 & 0,36 & 0,12 & 0,12 & 0,11 & 0,05 & 0,06 & 0,06 & 0,07 & 0,06 & 0,05 \\
\hline Bank Pocztowy & 0,44 & 0,38 & 0,31 & 0,15 & 0,11 & 0,05 & 0,04 & 0,04 & 0,05 & 0,05 & 0,05 & 0,05 \\
\hline GETIN Bank & 0,39 & 0,28 & 0,18 & 0,13 & 0,20 & 0,17 & 0,21 & 0,05 & 0,11 & 0,20 & 0,58 & 0,89 \\
\hline
\end{tabular}

$25 \mathrm{~W}$ modelu producenta do nakładów zaliczono majątek trwały oraz zatrudnienie, do efektów - należności oraz zobowiązania. W przyjętym w tym wypadku uproszczonym modelu działania banku zobowiązania zostały uznane za efekty jego funkcjonowania. Zatrudnienie wyrażono w liczbie etatów, zaś pozostałe wielkości nakładów i efektów w złotych, urealnione do poziomu cen z 2008 r. 


\begin{tabular}{|c|c|c|c|c|c|c|c|c|c|c|c|c|}
\hline \multirow{2}{*}{ Bank } & \multicolumn{12}{|c|}{$E_{\mathrm{VRS}}$} \\
\hline & 1996 & 1997 & 1998 & 1999 & 2000 & 2001 & 2002 & 2003 & 2004 & 2005 & 2006 & 2007 \\
\hline GE Money Bank & 0,24 & 0,16 & 0,18 & 0,17 & 0,31 & 0,45 & 0,57 & 0,39 & 1 & 0,89 & 0,77 & 0,92 \\
\hline Lukas Bank & 0,76 & 0,68 & 0,62 & 0,12 & 0,11 & 0,18 & 0,44 & 0,04 & 0,06 & 0,02 & 0,04 & 0,07 \\
\hline AIG Bank & 1 & 1 & 1 & 0,78 & 0,60 & 0,55 & 0,18 & 0,16 & 0,32 & 0,45 & 0,26 & 0,05 \\
\hline Invest-Bank & 0,26 & 0,17 & 0,20 & 0,07 & 0,06 & 0,11 & 0,05 & 0,04 & 0,05 & 0,05 & 0,04 & 0,04 \\
\hline Dominet Bank & 0,31 & 0,31 & 0,32 & 0,26 & 0,20 & 0,15 & 0,14 & 0,07 & 0,08 & 0,08 & 0,05 & 0,05 \\
\hline Rabobank & 0,98 & 0,71 & 0,78 & 1 & 1 & 1 & 1 & 1 & 1 & 1 & 1 & 1 \\
\hline Deutsche Bank & 1 & 0,70 & 0,44 & 0,31 & 1 & 1 & 1 & 0,26 & 0,28 & 1 & 0,24 & 0,21 \\
\hline WestLB Bank & 1 & 1 & 1 & 1 & 1 & 1 & 0,72 & 0,58 & 0,65 & 0,79 & 0,73 & 0,96 \\
\hline DZ Bank & 0,57 & 0,67 & 0,35 & 0,35 & 0,36 & 0,36 & 0,24 & 0,25 & 0,25 & 0,28 & 0,27 & 0,26 \\
\hline ABN Amro Bank & 1 & 1 & 1 & 1 & 1 & 1 & 1 & 0,19 & 0,33 & 0,36 & 0,24 & 0,22 \\
\hline Średnia & 0,68 & 0,66 & 0,66 & 0,61 & 0,64 & 0,63 & 0,61 & 0,50 & 0,54 & 0,55 & 0,55 & 0,54 \\
\hline
\end{tabular}

Źródło: Opracowanie własne na podstawie K. Chudy, M. Sobolewski, K. Stępień, Analiza efektywności banków w Polsce w latach 1996-2007, Oficyna Wydawnicza Politechniki Rzeszowskiej, Rzeszów 2012.

Dwa największe banki - Pekao oraz PKO BP - w tym wypadku charakteryzowały się najczęściej wskaźnikiem $E_{\mathrm{VRS}}$ równym 1. Również BRE charakteryzował się zwykle efektywnością techniczną (poza latami 1996-1997). Także Bank Handlowy w latach 1996-2003 w każdym z okresów wykazywał wskaźnik $E_{\mathrm{VRS}}$ na poziomie równym 1.

Dodatkowa analiza efektywności technicznej dla modelu producenta przeprowadzona w podziale grupy 27 banków na trzy odrębne grupy, do których zakwalifikowano banki uniwersalne, detaliczne i korporacyjne, wskazuje, że zróżnicowanie otrzymanych miar jest mniejsze oraz ich poziom jest wyższy. W tabeli 3 przedstawiono otrzymane wskaźniki efektywności technicznej analizowanych banków osobno dla każdej z wyodrębnionych pod względem profilu prowadzonej działalności grup banków. Interpretacji otrzymanych wyników można dokonywać tylko na tle grupy, w której znalazł się dany bank.

Średni poziom wskaźnika $E_{\mathrm{VRS}} \mathrm{w}$ grupie banków uniwersalnych w okresie 1998-2002 kształtował się na poziomie dziewięćdziesięciu kilku procent. Od 2003 r. wykazywał tendencję zniżkową. W omawianej grupie banków jednostkami dominującymi w całym okresie objętym analizą były Raiffeisen Bank oraz Bank Pocztowy. Największe banki uniwersalne (Pekao, PKO BP, BRE) zasadniczo charakteryzowały się wskaźnikiem $E_{\mathrm{VRS}}$ na poziomie równym 1 . W wypadku każdego z nich występowały lata, w których banki te wykazywały nieefektywność techniczną. 
Tabela 3. Wskaźniki efektywności technicznej analizowanych banków przy założeniu zmiennych efektów skali w latach 1996-2007 - wyniki uzyskane osobno dla każdej grupy banków

\begin{tabular}{|c|c|c|c|c|c|c|c|c|c|c|c|c|}
\hline \multirow{2}{*}{ Bank } & \multicolumn{12}{|c|}{$E_{\mathrm{VRS}}$} \\
\hline & 1996 & 1997 & 1998 & 1999 & 2000 & 2001 & 2002 & 2003 & 2004 & 2005 & 2006 & 2007 \\
\hline \multicolumn{13}{|l|}{ Banki uniwersalne } \\
\hline Pekao & 1 & 0,78 & 1 & 1 & 1 & 1 & 1 & 1 & 1 & 1 & 0,97 & 1 \\
\hline PKO BP & 1 & 1 & 1 & 1 & 1 & 1 & 1 & 1 & 1 & 1 & 1 & 0,73 \\
\hline BRE Bank & 0,90 & 0,78 & 1 & 1 & 1 & 1 & 1 & 1 & 1 & 1 & 1 & 1 \\
\hline ING Bank Śląski & 0,64 & 0,53 & 0,68 & 0,69 & 0,85 & 1 & 0,94 & 0,87 & 0,91 & 1 & 1 & 1 \\
\hline BZ WBK & 0,43 & 0,74 & 0,76 & 0,83 & 0,72 & 0,64 & 0,69 & 0,73 & 0,70 & 0,82 & 0,51 & 0,54 \\
\hline Bank Handlowy & 1 & 1 & 1 & 1 & 1 & 1 & 1 & 1 & 0,61 & 0,64 & 0,68 & 0,63 \\
\hline Bank Millennium & 1 & 0,80 & 1 & 1 & 0,85 & 0,73 & 0,69 & 0,66 & 0,68 & 0,53 & 0,67 & 0,94 \\
\hline Kredyt Bank & 0,31 & 0,82 & 1 & 1 & 1 & 0,99 & 0,88 & 0,72 & 0,68 & 0,66 & 0,52 & 0,67 \\
\hline Bank BGŻ & 1 & 1 & 1 & 0,77 & 0,73 & 0,68 & 0,74 & 0,58 & 0,44 & 0,43 & 0,44 & 0,50 \\
\hline Raiffeisen Bank & 1 & 1 & 1 & 1 & 1 & 1 & 1 & 1 & 1 & 1 & 1 & 1 \\
\hline Fortis Bank & 0,70 & 0,81 & 0,86 & 0,99 & 1 & 1 & 1 & 1 & 1 & 1 & 1 & 1 \\
\hline Bank BPH & 0,57 & 0,62 & 0,76 & 0,76 & 0,94 & 1 & 1 & 1 & 1 & 1 & 1 & 0,37 \\
\hline Nordea Bank & 0,54 & 0,60 & 0,83 & 0,94 & 0,98 & 0,82 & 1 & 0,88 & 1 & 1 & 1 & 1 \\
\hline BOŚ & 0,71 & 0,94 & 0,83 & 0,59 & 0,90 & 1 & 1 & 0,83 & 0,68 & 0,67 & 0,66 & 0,72 \\
\hline Bank DnB Nord & 1 & 1 & 1 & 1 & 1 & 1 & 0,91 & 1 & 1 & 1 & 1 & 1 \\
\hline Bank Pocztowy & 1 & 1 & 1 & 1 & 1 & 1 & 1 & 1 & 1 & 1 & 1 & 1 \\
\hline Średnia & 0,80 & 0,84 & 0,92 & 0,91 & 0,94 & 0,93 & 0,93 & 0,89 & 0,86 & 0,86 & 0,84 & 0,82 \\
\hline \multicolumn{13}{|l|}{ Banki detaliczne } \\
\hline GETIN Bank & 1 & 1 & 1 & 1 & 1 & 1 & 1 & 1 & 0,94 & 1 & 1 & 1 \\
\hline GE Money Bank & 1 & 0,84 & 1 & 1 & 1 & 1 & 1 & 1 & 1 & 1 & 1 & 1 \\
\hline Lukas Bank & 0,92 & 1 & 1 & 0,52 & 0,85 & 1 & 1 & 1 & 1 & 0,46 & 0,34 & 0,33 \\
\hline AIG Bank & 1 & 1 & 1 & 1 & 1 & 1 & 1 & 1 & 1 & 1 & 1 & 1 \\
\hline Invest-Bank & 1 & 1 & 1 & 1 & 0,49 & 0,55 & 0,57 & 0,67 & 0,75 & 0,69 & 0,81 & 0,96 \\
\hline Dominet Bank & 1 & 0,91 & 0,77 & 0,68 & 0,52 & 0,42 & 0,76 & 0,68 & 1 & 1 & 1 & 1 \\
\hline Średnia & 0,99 & 0,96 & 0,96 & 0,87 & 0,81 & 0,83 & 0,89 & 0,89 & 0,95 & 0,86 & 0,86 & 0,88 \\
\hline \multicolumn{13}{|c|}{ Banki korporacyjne } \\
\hline Rabobank & 0,98 & 0,71 & 0,78 & 1 & 1 & 1 & 1 & 1 & 1 & 1 & 1 & 1 \\
\hline Deutsche Bank & 1 & 0,70 & 0,44 & 0,31 & 1 & 1 & 1 & 0,26 & 0,28 & 1 & 1 & 0,21 \\
\hline WestLB Bank & 1 & 1 & 1 & 1 & 1 & 1 & 0,72 & 0,58 & 0,65 & 0,79 & 0,73 & 0,96 \\
\hline DZ Bank & 0,58 & 0,67 & 0,35 & 0,35 & 0,36 & 0,36 & 0,24 & 0,25 & 0,25 & 0,28 & 0,27 & 0,26 \\
\hline ABN Amro Bank & 1 & 1 & 1 & 1 & 1 & 1 & 1 & 0,19 & 0,33 & 0,36 & 0,24 & 0,22 \\
\hline Średnia & 0,91 & 0,82 & 0,71 & 0,73 & 0,87 & 0,87 & 0,79 & 0,46 & 0,50 & 0,68 & 0,65 & 0,53 \\
\hline
\end{tabular}

Źródło: Opracowanie własne na podstawie K. Chudy, M. Sobolewski, K. Stępień, Analiza efektywności banków w Polsce w latach 1996-2007, Oficyna Wydawnicza Politechniki Rzeszowskiej, Rzeszów 2012. 
W całym okresie objętym w grupie banków detalicznych AIG był efektywny technicznie. GE Money oraz Getin zdecydowanie najczęściej osiągały wskaźnik $E_{\mathrm{VRS}}$ na poziomie 1. Wśród banków korporacyjnych żaden bank nie wykorzystywał efektywnie zaangażowanych nakładów we wszystkich analizowanych latach. Rabobank, poza latami 1996, 1997 i 1998 osiągał wskaźnik efektywności technicznej równy 1. Bankiem o najniższej efektywności w każdym z badanych lat był DZ Bank.

\section{Podsumowanie}

W wyniku przeprowadzonych rozważań sformułowano spostrzeżenia dotyczące efektywności technicznej banków w Polsce w okresie poprzedzającym wystąpienie kryzysu finansowego. Na podstawie otrzymanych rezultatów analizy efektywności technicznej opartej na dwu koncepcjach działania banku nasuwa się kilka wniosków:

- W całym okresie objętym analizą w grupie badanych banków występowała średnia nieefektywność techniczna. Średni poziom efektywności technicznej $E_{\mathrm{VRS}}$ w poszczególnych latach jest wyższy dla modelu pośrednika niż dla modelu producenta. Wynika $z$ tego, że średni stopień nieefektywności technicznej przy takim założeniu w odniesieniu do zbioru nakładów i efektów w badanej grupie banków jest niższy.

- Wyższy poziom średniej nieefektywności technicznej w modelu producenta może być rezultatem sposobu ujęcia i wyrażenia efektów oraz samej ich klasyfikacji. Powstaje w związku z tym pytanie, czy w analizach efektywności technicznej banku z zastosowaniem koncepcji producenta, efekty nie powinny być wyrażone w liczbie prowadzonych przez bank rachunków lub udzielonych kredytów (mimo tego, że przyjmuje się wolumeny kwot depozytów czy kredytów jako dopuszczalne). Pytanie to jest ważne $z$ tego względu, że brak jest analiz efektywności technicznej banków w Polsce wykorzystujących zbiór efektów wyrażonych liczbą prowadzonych rachunków, przyjętych depozytów czy udzielonych kredytów.

- Poczynione uwagi skłaniają do sformułowania wniosku w formie otwartego pytania, mającego jednocześnie charakter postulatu badawczego na przyszłość. Biorąc pod uwagę fakt, że koncepcja pośrednika i producenta nie odzwierciedla dualnego charakteru banku oraz wieloasortymentowego charakteru oferty banków, czy analizy efektywności spełniałyby w większym stopniu postulat kompletności, gdyby były prowadzone równolegle, uwzględniając obie koncepcje funkcjonowania banku, a efektywność byłaby oceniana $\mathrm{z}$ obu tych perspektyw? 


\section{Bibliografia}

Bell F.W., Murphy N.B., Economies of scale and division of labor in commercial banking, "National Banking Review" 1968, No. 5.

Benston G.J., Branch Banking and Economies of Scale, "Journal of Banking and Finance" 1965, No. 20.

Berger A.N., Humprey D.B., Efficiency of Financial Institutions: International Survey and Directions for Future Research, "European Journal for Operational Research" 1997, No. 98.

Berger A.N., Humprey D.B., Megemergers in banking and the use of cost efficiency as an antitrust defense, "Antitrust Bulletin" 1992, No. 37.

Bikker J.A., Bos J.W.B., Bank Performance. A theoretical and empirical framework for analysis of profitability, competition and efficiency, "Routlege International Studies in Money and Banking" 2008.

Capiga M., Efektywność jako kryterium oceny banku, „Bank” 2002, nr 3.

Casu B., Molyneux P., Efficiency in European banking w: European banking. Efficiency, Technology and Growth, J. Goddard, P. Molyneux, J.O.S. Wilson, John Willey \& Sons Ltd., 2001.

Chudy K., Sobolewski M., Stępień K., Koncepcje funkcjonowania banku a zmiany produktywności banków giełdowych w Polsce, Wydawnictwo Uniwersytetu Szczecińskiego, „Zeszyty Naukowe Uniwersytetu Szczecińskiego” 2009, nr 548, seria Ekonomiczne problemy ustug.

Chudy K., Sobolewski M., Stępień K., Wpływ klasyfikacji nakładów i efektów w działalności banku na zmiany produktywności banków giełdowych $w$ Polsce, Wydawnictwo Naukowe Politechniki Rzeszowskiej, „Zarządzanie i Marketing” 2009, nr 4(16).

Chudy K., Sobolewski M., Stępień K., Wpływ umiejscowienia depozytów w nakładach lub efektach na produktywność banków giełdowych w Polsce, w: Współczesne Finanse. Stan i perspektywy rozwoju bankowości, red. L. Dziawgo, Wydawnictwo Naukowe Uniwersytetu Mikołaja Kopernika, Toruń 2008.

Ferrier G.D., Lovell C.A.K., Measuring Cost Efficiency in Banking: Econometric and Linear Programming Evidence, "Journal of Econometrics" 1990, Vol. 46, No. 1-2.

Freixas X., Rochet J.Ch., Mikroekonomia bankowa, CeDeWu, Warszawa 2007.

Gilbert R.A., Bank Market Structure and Competition: A Survey, "Journal of Money, Credit and Banking" 1984, Vol. 16, No. 4.

Gospodarowicz M., Procedury analizy i oceny banków, „Materiały i Studia NBP” 2000, nr 103.

Heffernan S., Nowoczesna bankowość, PWN, Warszawa 2007.

Humprey D.B., Cost and Scale Economies in Bank Intermediation w: Handbook for Banking Strategy, R. Aspinwall, R. Eisenbeis, Wiley\&Sons, New York 1985.

Jajuga K., Statystyczna analiza wielowymiarowa, PWN, Warszawa 1993. 
Kolari J., Zardkoohi A., Bank Cost, Structure and Performance, Lexington Books, Lexington 1987.

Pawłowska M., Efektywność, konkurencyjność i koncentracja na polskim rynku usług bankowych w latach 1997-2002 - zwiąki między pojęciami, „Bank i Kredyt” 2003, nr 6.

Pawłowska M., Konkurencja w sektorze bankowym. Teoria i wyniki empiryczne, C.H. Beck, Warszawa 2014.

Pawłowska M., Wpływ zmian w strukturze polskiego sektora bankowego na jego efektywność w latach 1997-2002 (podejście nieparametryczne), „Bank i Kredyt” 2003, nr 11-12.

Rogowski G., Metodologia analiz efektywności i efektu skali banków, „Bank i Kredyt” 1998, nr 11.

Rogowski G., Metody analizy i oceny działalności banku na potrzeby zarzadzania strategicznego, Wydawnictwo Wyższej Szkoły Bankowej w Poznaniu, Poznań 1998.

Sealey C.W., Lindley J.T., Inputs, Ouputs and Theory of Production and Cost for Financial Institutions, "Journal of Finance",1997, No. 32.

Siudek T., Wpływ poziomu konkurencji na efektywność działania banków spółdzielczych w Polsce - teoria i praktyka, Szkoła Główna Gospodarstwa Wiejskiego w Warszawie, „Roczniki Naukowe” 2008, t. 10, z. 1.

Stępień K., Konsolidacja a efektywność banków w Polsce, CeDeWu, Warszawa 2004.

Wheelock D.C., Wilson P.W., Evaluating the Efficiency of Commercial Banks: Does Our View of What Banks Do Matter?, "Review of Federal Reserve Bank of St. Louis" 1995, Vol. 77, No. 7-8.

\section{Some Remarks about Studying of the Banks' Effectiveness. The Example of Poland}

The paper addresses impact of application of intermediation and production approaches on the technical efficiency of banks measurement result. Placement of deposits in both models and the lack of clear decisions as to the nature of banks are important issues. The analysis shows that the level of technical-efficiency estimated for the analyzed banks, taking into account production approach, is lower than the level of technical efficiency for the intermediation approach.

Keywords: technical efficiency, intermediation approach, production approach, banks' inputs and outputs 


\section{Quelques remarques sur les recherches sur l'efficacité des banques: l'exemple de la Pologne}

Larticle traite de l'impact de l'adoption du modèle de courtage ou de production sur les résultats de l'efficacité technique des banques. Une question importante est de déterminer la place des dépôts dans les deux modèles; une autre est l'absence des décisions claires quant à leur caractère dans la banque. L'analyse montre que le niveau de l'efficacité technique estimé pour les banques dans le modèle de production est inférieur au niveau dans le modèle de courtage.

Mots-clés: l'efficacité technique, le modèle de courtage, le modèle de production, la classification des coûts et des bénéfices de la banque

\section{Несколько замечаний относительно анализа эффективности банков. Казус Польши}

В статье рассматриваются последствия применения посреднического или производственного подходов для получаемых результатов измерений технической эффективности банков. Особенно важны размещение депозитов в обоих подходах и отсутствие четких решений, определяющих их место в банковской компании. Исследование показывает, что уровень технической эффективности проанализированных банков при использовании производственного подхода ниже, чем при посредническом подходе.

Ключевые слова: техническая эффективность, посреднический подход, производственный подход, классификация затрат и выгод банка 